Original Paper

\title{
Diversifikasi Pendapatan Alternatif Masyarakat Nelayan Melalui Inovasi Teknologi Budidaya Rumput Laut Di Desa Batunamparselatan Lombok Timur
}

\author{
Karnan $^{1 *}$, Agil Al Idrus ${ }^{1}$, Imam Bachtiar', Ahmad Raksun', I Wayan Merta1 \\ ${ }^{1}$ Program Studi Pendidikan Biologi Fakultas Keguruan dan Ilmu Pendidikan, Universitas Mataram
}

*Corresponding Author:

Karnan, Program Studi

Pendidikan Biologi

Fakultas Keguruan dan

Ilmu Pendidikan,

Universitas Mataram,

Indonesia;

Email: 1:

karnan.ikan@unram.ac.id

\begin{abstract}
Abstrak: Rumput laut merupakan salah satu komoditas unggulan di Nusa Tenggara Barat. Tetapi kuantitas dan kualitas komoditas yang strategis ini masih belum sesuai dengan yang diharapkan. Hal ini disebabkan oleh kendala teknis yang ada dalam budidaya dan penanganan pasca panen. secara khusus, kegiatan ini dimaksudkan untuk : mengatasi persoalan yang menyebabkan penurunan produksi dan kegagalan panen yang dialami pembudidaya rumput laut di lokasi kegiatan, meningkatan produksi rumput laut, mengatasi persoalan rendahya kualitas rumput laut yang disebabkan oleh alga filamen sebagai kompetitor (biofouling) dan proses penanganan pasca panen, serta meningkatkan posisi tawar pembudidaya dalam menentukan harga jual rumput laut. Metode yang diterapakn dalam kegiatan ini meliputi metode yang lebih mengedepankan suatu kegiatan agar paket teknologi yang ingin disampaikan dapat dengan mudah ditiru untuk dipraktekkan. Karena itu, metode konvensional khususnya ceramah dan diskusi tetap digunakan dan dikombinasi dengan metode lain, yaitu demonstrasi dan praktek lapangan (praktek langsung). Hal ini sesuai dengan karakteristik masyarakat petani pada umumnya yang memiliki tingkat pendidikan yang rendah. Selain itu, pertimbangan waktu bagi pelaksanaan kegiaan ini yang juga sangat terbatas
\end{abstract}

Kata Kunci: Diversifikasi Pendapatan Alternatif; Masyarakat Nelayan; Inovasi teknologi; Budidaya rumput laut

\section{Pendahuluan}

Peningkatan permintaan terhadap bahan makanan dari laut terutama sumberdaya ikan, tidak hanya berasal dari masyarakat lokal, tetapi juga berasal dari pasar luar daerah bahkan luar negeri. Permintaan pasar yang terus meningkat terhadap sumberdaya tersebut telah memaksa nelayan untuk melakukan penangkapan terhadap sumberdaya ikan dengan cara yang merusak (desructive), seperti penggunaan potassium, bom, dan beraneka ragam bentuk alat tangkap yang tidak ramah lingkungan. Teknik penangkapan ini telah terbukti memberikan dampak yang sangat buruk tidak hanya terhadap habitat ikan, seperti terumbu karang dan padang lamun, tetapi juga terhadap sumberdaya ikan itu sendiri. Jika kondisi ini dibiarkan terus berlangsung dapat berdampak negatif terhadap kehidupan masyarakat yang selama ini menggantungkan kehidupannya dari sumberdaya ini.
Indikasi bahwa telah terjadi upaya tangkap lebih terhadap sumberdaya ikan dapat dilihat dimana-mana. Beberapa dampak yang dapat timbul sekaligus menjadi penciri perikanan overfising adalah menurunnya hasil tangkapan per satuan usaha (Murdiyanto 2004), waktu melaut menjadi lebih panjang dari biasanya, ukuran mata jaring menjadi lebih kecil dari biasanya, ukuran ikan target semakin kecil, dan biaya operasional semakin tinggi (Widodo dan Suadi 2006). Kondisi ini dirasakan hampir di semua lokasi oleh semua nelayan. Organisasi Pangan dan Pertanian Dunia (FAO) memperkirakan $75 \%$ dari perikanan laut dunia sudah tereksploitasi penuh, mengalami tangkap lebih atau stok yang tersisa bahkan sudah terkuras-hanya $25 \%$ dari sumber daya masih berada pada kondisi tangkap kurang (FAO 2002). Saat ini, ciri dasar dari sumber daya perikanan dunia menunjukkan gejala yang terus menerus ke arah penipisan berbagai stok ikan yang disertai dengan tingginya tingkat modal dan tenaga kerja yang 
ditanamkan untuk kegiatan penangkapan. Kondisi ini juga diikuti oleh hasil tangkapan yang rendah serta sedikitnya pendapatan yang dapat diterima oleh nelayan.

Dari lima komodias unggulan yang ditangkap di perairan Selat Alas, Nusa Tenggara Barat, dilaporkan bahwa hanya ikan teri dan kakap merah yang tingkat pemanfaatannya masih masih di bawah jumlah tangkapan yang diperbolehkan (JTB), sedangkan tiga jenis ikan lainnya, lemuru, tembang, dan cumi-cumi telah melampaui JTB (Karnan et al 2012a). Karnan et al (2012b) menambahkan bahwa penangkapan cumi-cumi di Selat Alas tidak hanya melampaui JTB, tetapi juga telah melampaui potensi lestarinya.

Kondisi seperti yang digambarkan di atas telah memaksa nelayan yang sebelumnya menangkap ikan untuk beralih profesi. Beberapa nelayan beralih profesi menjadi pembudidaya, misalnya budidaya ikan dalam sistem keramba jaring apung (KJA) dan budidaya rumput laut. Budidaya dalam sistem KJA memerlukan waktu yang relatif lama dan modal yang cukup tinggi sehingga kegiatan ini hanya cocok bagi nelayan yang kebutuhan sehari-harinya sudah terpenuhi dari sumber lain. Sementara sebagian besar nelayan yang ada di NTB merupakan nelayan skala kecil yang pendapatannya diperoleh dari usaha menangkap ikan setiap hari. Budidaya rumput laut merupakan usaha samping yang bisa diandalkan karena siklus usahanya yang singkat dan relatif tidak memerlukan modal yang banyak.

Kabupaten Lombok Timur, terutama di kawasan Teluk Ekas, merupakan salah satu sentra produksi rumput laut utama di Nusa Tenggara Barat. Pemda NTB (2007) mencatat bahwa luas potensi budidaya rumput laut di di Lombok Timur adalah 2000 hektare, dan potensi terluas ada di Teluk Ekas. Mengingat potensi yang besar ini, pengembangan komoditas rumput laut telah dijadikan sebagai komoditas unggulan yang dikembangkan di NTB selain sapi dan $\mathrm{j}$ agung. Di kawasan Teluk Ekas terdapat beberapa lokasi masyarakat pembudidaya rumput laut, yaitu Batunampar, Saung, Ujung, dan Ekas. Pada awalnya, kegiatan ini pernah menjadi kegiatan ekonomi sampingan masyarakat nelayan yang dapat diandalkan. Dalam beberapa tahun terakhir, usaha budidaya rumput di seluruh wilayah Nusa Tenggara Barat, termasuk di Batunampar, pada umumnya "gagal". Serangan penyakit ice-ice dan biofouling adalah penyebab utama kegagalan dalam budidaya rumput laut di kawasan Teluk Ekas (Karnan et al, 2013).

Dalam budidaya rumput laut, kehadiran penyakit "ice-ice" dan alga competitor (biofouling) merupakan ancaman paling serius bagi pembudidaya rumput laut. Serangan kedua musuh pembudidaya ini terjadi pada musim-musim tertentu, dan ketika menyerang maka peluang panen bagi pembudidaya menjadi sangat kecil. Penyakit ice-ice menyebabkan rontoknya thalli dari rumput laut yang dibudidaya, bahkan dapat menghancurkan rumput laut dalam waktu singkat yaitu dua minggu (Yulianto, 2004; Largo, 2002). Kehadiran alga competitor dalam budidaya rumput laut, misalnya Euchema cottoni, sangat mengganggu. Biota ini hidup memanfaatkan rumput laut yang dibudidaya sebagai media tempat tinggalnya sehingga menjadi pesaing utama dalam memperoleh nutrisi dan ruang. Ketika hal ini terjadi, maka rumput laut yang dibudidaya biasanya kalah dalam bersaing, sehingga tidak bisa tumbuh baik karena diselimuti oleh alga foulilng tadi.

Ketidak mampuan rumput yang dibudidaya bertahan terhadap serangan ice-ice dan alga kompetitor disebabkan oleh kondisi awal bibit yang tidak sehat. Oleh karena itu, bibit yang ditanam seharusnya dapat dipastikan dalam kondisi sehat. Salah satu metode untuk mendapatkan bibit yang sehat adalah sebelum ditanam, bibit terlebih dahulu diberi perlakuan tertentu sehingga dipastikan dalam kondisi sehat. Salah satu perlakuan yang dimaksud adalah dengan memberikan nutrisi dan hormon pertumbuhan yang cukup terhadap bibit rumput laut sebelum ditanam. Suatu studi awal yang pengusul pernah lakukan adalah dengan membandingkan antara bibit rumput laut yang ditanam secara konvensional (tanpa perlakuan) dan bibit yang sebelumnya diberi perlakuan tertentu yaitu memberikan nutrisi yang lengkap kepada bibit sebelum ditanam. Hasil ujicoba menunjukkan bahwa bibit rumput perlakuan tumbuh lebih cepat, bebas ice-ice dan tidak tertempel oleh biofouling (http://disantyaalamhijau.blogspot.com/). Atas dasar itu, maka inovasi teknologi baru yang mudah diimplementasikan ini memberikan harapan baru sebagai salah satu alternatif dalam mengatasi kegagalan dalam budidaya rumput laut. 


\section{Metode Pelaksanaan}

Pendekatan yang diterapakan dalam kegiatan yang dilakukan pada thaun 2014 ini adalah pendekatan yang lebih mengedepankan suatu kegiatan agar paket teknologi yang ingin disampaikan dapat dengan mudah ditiru untuk dipraktekkan, terutama demonstrasi dan percobaan lapangan. Hal ini sesuai dengan karakteristik masyarakat petani dan pembudidaya di daerah ini yang pada umumnya berpendidikan rendah.

Keseluruhan rencana kerja dalam program ini melilputi: persiapan, sosialisasi program, dan pembuatan proyek percontohan budidaya. Kegiatan persiapan meliputi persiapan materi, alat dan bahan sosialisasi dan budidaya. Sosialisasi program dimaksudkan agar pihak mitra mendapatkan pengetahuan dasar dan memiliki kesiapan secara psikologis yang memadai terkait pelaksanaan program yang akan dilaksanakan. Program pembuatan proyek percontohan (pilot project) diharapkan dapat memberikan pengalaman baru bagi pihak masyarakat pembudidaya sehingga mereka mudah mengaplikasikannya dalam kegiatan bisnis budidaya rumput laut pada waktu yang akan datang dengan kualitas tinggi sesuai permintaan pasar.

\section{Hasil dan Pembahasan}

Kegiatan pengabdian pada masyarakat yang dilakukan di desa Batunampar Selatan, Jerowaru, Kabupaten Lombok Timur ini dapat dilaksanakan sesuai waktu yang telah direncanakan. Selama proses pelaksanaan pengabdian dilaksanakan, terlihat adanya dampak positif dari kegiatan yang dialaksanakan. Selain dampak positif, beberapa kondisi juga muncul sebagai penghambat kegiatan.

Seperti yang diuraikan sebelumnya bahwa kegagalan panen rumput laut terjadi karena serangan penyakit ice-ice dan gangguan biota/gulma penempel biofouling. Dalam percontohan yang dilakukan pada kegiatan pengabdian di Batunampar Selatan ini, penyakit ice-ice tidak muncul. Dalam percontohan ini, rataan (mean) bobot rumput laut Euchema cottoniiyang dibudidaya di Batunampar Selatan, bobot panen yang didapatkan belum mencapai standar minimal yang diharapkan. Berdasarkan Standar Nasional
Indonesia (SNI) 7579.2:2010, bobot rumput laut dengan berat tanam 100 gram, bobotnya dapat mencapai lebih dari 500 gram setelah berumur 45 hari. Dalam percontohan ini, rataan bobot tertinggi yang dicapai adalah 483,75 gram.

Kondisi di atas diperkirakan sebagai dampak faktor lingkungan yang ada selama penanaman kurang menguntungkan, yaitu angin kencang dan banyaknya sampah yang masuk ke dalam teluk Ekas. Angin kencang dan timbunan sampah yang sangat menonjol selama penanaman dilakukan mengganggu kestabilan rakit budidaya. Hal ini sesuai dengan pendapat de Goes dan Reis (2011) yang menyebutkan angin kencang (badai), suhu dan salinitas dapat mengganggu pertumbuhan harian rumput laut E. cottonii. Selain itu, De San (2012) secara lebih lengkap menyebutkan bahwa beberapa faktor yang dapat mengganggu pertumbuhan rumput laut yang dibudidaya, diantaranya alga parasit, dimakan ikan, penyakit ice-ice, suhu air laut yang tinggi, badai, dan masukan air tawar. Selain itu, dalam beberapa tahun terakhir ini, di beberapa lokasi di kawasan teluk Ekas berlangsung pengambilan sargassum. Pengambilan sargassum yang dilakukan secara liar ini pun memiliki dampak buruk terhadap kegiatan budidaya rumput laut. Sisa-sisa sargassum yang terlepas di perairana bebas setelah dipotong sebagian ada yang terapung dan hanyut terbawa arus laut. Sargassum yang hanyut ini tidak jarang tersangkut di keramba budidaya. Sargassum ini biasanya tumbuh subur melebihi tanaman rumput laut yang dibudidaya. Dengan demikian, pengambilan sargassum secara liar ini juga dapat berpengaruh terhadap keberhasilan budidaya rumput laut yang dilakukan.

Dengan kondisi yang digambarkan di atas maka target untuk meningkatkan produksi rumput laut belum dapat diwujudkan. Walaupun demikian, serangan ice-ice yang biasanya menyerang tanaman rumput laut yang dibudidaya kalil ini tidak terlihat.

Selama ini, pembudidaya rumput laut memiliki posisi tawar yang renadah dalam menentukan harga rumput laut. Hal ini disebabkan kualitas rumput laut yang dihasilkan umumnya berkualitas rendah. Kualitas rendah ini ditimbulkan oleh pengelolaan budidaya dan penanganan pasca panen yang kurang baik. Pemanenan rumput laut yang berumur kurang dari umur panen yang ideal, misalnya 45 hari, menyebabkan kandungan karageenan rumput laut rendah. Telah menjadi 
kondisi umum bahwa para pembudidaya di daerah ini mengeringkan rumput laut dengan cara menjemurnya di atas permukaan tanah atau pasir tanpa diberi alas. Kondisi ini menyebabkan rumput laut bercampur dengan berbagai jenis kotoran, misalnya pasir/tanah dan kotoran benda asing lainnya. Karena itu, dalam pengabdian kali ini, tim menyarankan untuk memperhatikan secara sungguh-sungguh umur panen dan cara penanganan pasca panen yang dilakukan. Tim smerekmendasikan beberapa cara pengeringan, misalnya mengguakan sistem gantung (hanging system), menjemur menggunakan para-para, bahkan menjemur di atas keramba di tengah laut.

Budidaya rumput laut merupakan kegiatan ekonomi utama yang dilakukan oleh masyarakat di lokasi pengabdian. Ketika suatu musim tanam terganggu, maka hal ini dapat berdampak serius terhadap perekonomian masyarakat setempat. Untuk mempertahankan hidupnya, masyarakat di lokasi pengabdian melakukan berbagai jenis kegiatan ekonomi, misalnya nelayan kecil. Dilihat dari sarana dan pasaran tangkap yang dimiliki, serta jenis sumberdaya yang ditangkap sperti ikan belanak, rajungan, dan beberapa jenis ikan pantai lainnya. Usaha penangkapan ikan mereka lakukan di perairan dangkal dekat dengan kampung mereka. Dengan gambaran seperti ini, maka tim pengabdian menilainya sebagai salah satu faktor yang mendorong perlunya dilaksanakan pengabdian di lokasi ini.

Kondisi laut yang sangat dinamis, seperti angin kencang, gelombang tinggi, tinggi pasokan air tawar, dan banyak sampah, menjadi faktor pembatas sehingga budidaya rumput laut tidak dapat dilakukan sepanjang tahun. Seperti yang diuraikan sebelumnya bahwa kondisi angin kencang dan banyaknya sampah yang mengotori perairan dan menyelimuti tanaman budidaya rumput laut pada saat percobaan dilakukan menjadi penyebab uji coba budidaya rumput laut yang dilakukan tidak berjalan sebagaimana mestinya.

Untuk memenuhi kebutuhan seharihari,’masyarakat di lokasi pengabdian melakukan berbagai macam kegiatan ekonomi, misalnya menangkap ikan, budidaya ikan dan lobster dengan sistem keramba jaring apung, dan lain-lain. Akhirakhir ini muncul mata pencaharian baru yaitu mengoleksi anakan lobster yang oleh masyarakat setempat dikenal dengan "sistem pocong." Penangkapan anakan lobster dengan sistem ini relatif sederhana, yaitu menggunakan bungkus (sak) semen yang dilipat sedemikian rupa sehingga membentuk kompleksitas tertentu. Penagakapan dilakukan pada malam hari dengan menggunakan sinar lampu sebagai alat bantu untuk menarik berkumpulnya anakan lobster ke "pocong" yang disiapkan di dalam air. Anakan lobster akan menuju pocong dan menempati lipatan sak semen yang dibentuk. Dalam hal ini, "pocong" lebih berfungsi sebagai kolektor. Pagi hari, para kolektor akan mengangkat pocong yang dipasang, dan anakan lobster yang didapatkan dikeluarkan dari lipatan sak semen. Anakan lobster sudah siap dipasarkan. Para kolektor tidak perlu mencari pasar yang jauh untuk menjual hasilnya karena di lokasi setempat sudah ditunggu oleh pedagang yang siap menampung hasil tangkapan pada hari itu.

Menurut informasi yang didapatkan dari beberapa kolektor, dari hasil tangkapan yang dilakukan semalam saja, seorang kolektor dapat menghasilkan uang puluhan, ratusan, bahkan jutaan rupiah. Satu hal yang disukai para kolektor adalah mereka secara langsung mendapatkan pembayaran secara tunai pada saat mereka menjual hasilnya hari itu juga tanpa penundaan.

Kondisi di atas juga menjadi penghambat pelaksanaan kegiatan pengabdian pada masyarakat kali ini. Dalam usaha sebagai kolektor anakan lobster, komponen yang memerlukan modal cukup besar adalah dalam penyediaan rakit apung dan mesin gen set. Mengingat tidak semua masyarakat mampu menyediankan komponen dasar ini, maka tidak semua masyarakat juga mampu beralih pekerjaan seabagai kolektor anakan lobster ini.Selain itu, karena pengumpulan anakan lobster dilakukan pada malami, sebagian dari mereka juga masih tertarik untuk melakukan budidaya rumput laut yang secara finansial memerlukan biaya yang jauh lebih rendah dibandingkan dengan usaha sebagai kolektor anakan lobster.

\section{Kesimpulan}

Berdasarakan pengalaman selama kegiatan pengabdian dilakukan, diperoleh kesimpulan: 1) Usaha budidaya rumput laut masih dapat dianggap sebagai kegiatan ekonomi yang strategis untuk dilakukan desa Batunampar Selatan. 2) Inovasi budidaya dengan melakukan pemupukan 
menggunakan pupuk organik cair (POC) memberikan dampak positif terhadap pertumbuhan rumput laut.

\section{Daftar Pustaka}

[FAO] Food Agriculture Organization. 2002. The state of the world fisheries and aquaculture 2002. FAO, Rome: FAO, 150 pp.

de Goes and RP Reis. 2011. Temporal variation of the growth, carrageenan yield and quality of Kappaphycus alvarezii (Rhodophyta, Gigartinales) cultivated at Sepetiba bay, souteastern Brazilian coast. J. Appl Phycol. DOI 10.1007/S10811-011-9665-4.

De San M. 20123. The Farming of Seaweed. Implementation of a Regional Fisheries Strategy For The Eastern-Southern Africa and India Ocean Region. REPORT/RAPPORT : SF/2012/28.

Karnan, Al Idrus. A, Bachtiar. I, Mahrus, Raksun. A, Azizah. A, 2013, Pemanfaatan Pupuk Organik Cair untuk Meningkatkann Produksi pada Budidaya Rumput Laut, Laporan Pengabdian Pada Masyarakat, FKIP Universitas Mataram.

Karnan, M S Baskoro, Iskandar B H, E. Lubis, dan Mustaruddin, 2012a, Potensi dan tingkat pemanfaatan sumberdaya ikn unggulan di perairan Selat Alas, Nusa Tenggara Barat, Buletin PSP Vol 20 nomor 4 Desember 2012.

Karnan, M S Baskoro, Iskandar B H, E. Lubis, dan Mustaruddin, 2012b, Perikanan cumi-cumi di Perairan Selat Alas Nusa Tenggara Barat, Jurnal Biologi Tropis Vol 13 N0 1 Januaari 2012.

Largo, D.B. 2002. Recent developments in seaweed diseases. In: A.Q.Hurtado, N.G. Guanzon, Jr., T.R. de Castro-Mallare, \& M.R.J. Luhan (Eds.) Proceedings of the National Seaweed Planning Workshop held on August 2-3, 2001, SEAFDEC Aquaculture Department, Tigbauan, Iloilo. (pp. 35-42). Tigbauan, Iloilo: SEAFDEC Aquaculture Department.

Murdiyanto B. 2004. Pengelolaan sumber daya perikanan pantai. Jakarta: Proyek Pengembangan Masyarakat Pantai dan pengelolaan Sumber daya Perikanan.
Direktorat Jenderal Perikanan Tangkap Departemen Kelautan dan Perikanan.

Pemda Provinsi NTB. 2009. Sapi Jagung Rumput Laut (PIJAR). Pemerintah Propinsi Nusa Tenggara Barat. Mataram.

Yulianto, K. 2004. Fenomena faktor pengontrol penyebab kerugian pada budidaya karaginofir di Indonesia. Oseana Vol XXIX no $2: 17-23$. 